\title{
Misinformation About Breast Cancer Screening and the Possible Unanticipated Importance of Detecting Ductal Carcinoma In Situ
}

\section{Daniel B. Kopans*}

Department of Radiology, Harvard Medical School, Boston

Breast Imaging Division, Massachusetts General Hospital

\author{
${ }^{*}$ Corresponding author: \\ Daniel B. Kopans, M.D. \\ Professor of Radiology \\ Harvard Medical School \\ Founder - Breast Imaging Division \\ Massachusetts General Hospital \\ 20 Manitoba Road \\ Waban, Massachusetts 02468 \\ Tel: 617-584-4584 \\ E-Mail: dkopans@verizon.net

\section{Abbreviations:} \\ DCIS: Ductal Carcinoma In Situ, \\ NCI: National Cancer Institute, \\ ACP: American College of Physicians, \\ USPSTF: United States Preventive \\ Services Task Force, \\ RCT: Randomized, controlled trials.
}

\section{Rezumat}

De mai multe decenii există un efort continuu de a limita accesul la screening-ul cancerului mamar, efort bazat pe argumente nesusținute ştiințific. Fiecare argument adus împotriva screeningului a fost respins de ştiință. Aceste probleme sunt prezentate pe scurt în acest articol. Dezbateri largi au legitimat preocupările legate de importanța şi tratamentul unei varietăți de leziuni clasificate drept carcinom ductal in situ (CDIS). Acestea sunt aproape sigur leziuni precursoare ale cancerului mamar invaziv. Ce s-a omis de fapt în discuții este faptul că, în SUA, incidența cancerului mamar invaziv a crescut constant din 1940, cu 1-1,3\% pe an. $\mathrm{Cu}$ toate acestea, încă de la începutul screening-ului incidența cancerului mamar invaziv a fost mai scăzută decât extrapolau aşteptările. Este probabil că îndepărtarea CDIS, datorită screening-ului mamografic, să fie responsabilă de incidența mai mică a cancerelor invazive.

Cuvinte cheie: cancer mamar, carcinom ductal in situ, CDIS, screening

\section{Abstract}

For decades there has been an unrelenting effort to limit access to breast cancer screening based on scientifically unsupportable arguments. As each argument has been raised against screening it has been refuted by science. These issues are summarized below. Within the larger debate have been legitimate concerns about the 
importance and treatment of a range of lesions classified as Ductal Carcinoma In Situ (DCIS). These are almost certainly precursor lesions to invasive breast cancer. What has been lost in the discussions is the fact that, in the U.S., the incidence of invasive breast cancer had been increasing steadily since 1940 , at $1-1.3 \%$ per year. However, since the start of screening the incidence of invasive breast cancer is lower than the extrapolated expectation. It is likely that the removal of DCIS, due to mammographic screening, has resulted in fewer subsequent invasive cancers.

Key words: breast cancer, ductal carcinoma in situ, DCIS, screening

\section{Introduction}

Unfortunately, there has been a great deal of misinformation about breast cancer screening that has passed poor peer review and has been published in some of our most prestigious journals $(1,2,3,4)$. These have been repeated by the media causing a great deal of confusion. My hope is to address several of the main issues that have been raised and misreported about screening and to provide the answers based on the scientific evidence.

Among the areas of confusion are the earliest breast cancers known collectively as Ductal Carcinoma In Situ (DCIS). These remain a difficult spectrum of lesions with respect to how they should be treated. I think it is almost certain that the vast majority of cancers begin in the ducts of the breast as DCIS, but the "natural history" of these lesions and which ones and why they progress to invasion remains unclear. As a consequence of the, scientifically, contrived suggestion of massive overdiagnosis of breast cancer, a potentially major factor has been overlooked in the denigration of screening in the effort to try to reduce access to mammography. I believe there are data that can improve our understanding of the progression of some DCIS lesions to invasive breast cancer. The fact that there has been so much misinformation about breast cancer in general has likely interfered with our ability to determine the importance of DCIS.

\section{Screening Guidelines in the U.S. over time}

In the 1980's there was no agreement as to the age at which to start screening and the frequency. In 1989 the major medical groups, including the National Cancer Institute (NCI), reached a "Consensus" and advised that women ages 40-49 get screened every one to two years and women ages 50 and over be screened every year (5). In 1993 the U.S. National Cancer Institute (NCI), using inappropriate statistical analysis (6), dropped support for screening women ages 40-49 and advised women ages 50 and over to be screened every two years (7). In 1997, when the benefit for women ages 40-49, analyzed separately, became statistically significant (8), NCI once again supported screening starting at the age of 40 (9). In 2007 the American College of Physicians (ACP) went back and decided that women should wait until the age of 50 and be screened every two years (10). This position was adopted by the ACP's close ally, the United States Preventive Services Task Force (USPSTF) in 2009 (11). The USPSTF reaffirmed this position in 2016 (12).

In an astonishing "guidance document", on April 8 of 2019, the ACP reaffirmed their support for the USPSTF and told women that they should wait until the age of 50 and be screened every two years (13). They cited the "harms" of screening but forgot to point out that delaying screening has no effect on the major "harms" related to screening ("overdiagnosis" and "overtreatment") [see below]. Since everyone agrees that delaying screening will result in avoidable, unnecessary deaths, and since the only "harm" that is affected by delaying screening is the "false positives" (recalls from screening), it would appear that the ACP Panel (that prohibited experts in 
screening from participating) thought it best that tens of thousands of women die, unnecessarily, whose lives could be saved by annual screening starting at the age of 40 (14), in order to avoid the anxiety of being recalled for a few extra pictures or an ultrasound and a $2 \%$ chance of a needle biopsy.

It is with this as a backdrop that I hope that those who are responsible for advising women will recognize the consequences of not having experts on panels to prevent them from making such outrageous, dangerous, and unethical decisions.

\section{Fundamental facts:}

The RCT'S proved that screening saves lives for women ages 40-74

Randomized, controlled trials (RCT) eliminate leadtime bias, length bias sampling, selection bias, pseudo disease bias, etc. They have proven the early detection of breast cancers using mammography screening, reduces deaths for women ages 40-74 $(15,16)$. These are the ages of the women who participated in the trials and it has been shown for all these women that there were, statistically significantly, fewer deaths among those allocated to screening compared to those assigned to the control arms (17). Most are unaware that RCT's, by their very design, underestimate the benefit. Since women cannot be forced to participate in a trial, they are "invited". A woman allocated to the screening arm may refuse the invitation ("noncompliance"), but if she dies from breast cancer she is still counted as having been screened! Conversely, if she is assigned to the control arm, she can still go out and get a mammogram on her own ("contamination"). If her life is saved by the mammogram, she is still counted as an unscreened control! Since there was "noncompliance" and "contamination" in all of the trials, the RCT's underestimated the benefit. This means that mortality reduction is greater than what is often published. The RCT's proved the fundamental concept that screening saves lives, but it is a mistake to think that they provide an absolute measure of the benefit as has been (falsely) suggested by some panels.

\section{Observational studies confirm the benefit in general populations}

Having been proven in RCT's, the benefits of screening have been confirmed in numerous observational studies in which women in the general population, with access to screening, have much better survival than those who do not have access (18-34). It is in these analyses of women ages 40 and over, who actually participate in screening, that the data show a greater than $40 \%$ reduction in deaths.

\section{Additional confirmation of screening benefit}

A third way of evaluating benefit is in a "failure analysis". In a review of women who died from breast cancer in the Harvard teaching hospitals, $71 \%$ of the deaths were among the $20 \%$ of the women who were not participating in screening despite all of the women having access to modern therapy (35). Spencer et al reported similar results (36).

More recently, in still another way to test the benefits from screening, a very large study of the incidence of death among women in Sweden who participated in mammography screening compared to those who had not showed a, statistically significant, $41 \%$ reduction in their risk of dying from breast cancer within 10 years associated with a $25 \%$ reduction in the rate of advanced breast cancers (37).

\section{The U.S. experience}

In the U.S. mammography screening began in the mid 1980's (38) signaling the beginning of a prolonged prevalence peak as more and more women participated in screening over the next decade. As predicted, the death rate from breast cancer that had been unchanged for decades in the U.S., began to fall in 1990, soon after the start of screening. The death rate has continued to decline as more and more women have participated in screening so that there are now more than 40\% fewer women dying each year from breast cancer with an estimated more than 600,000 lives 
saved since 1990 (39). Therapy has improved, but there is still no cure for advanced breast cancers. Therapy may extend lives, but breast cancer is cured when it is treated earlier. Unfortunately (and inexplicably), the Surveillance Epidemiology and End Results program of the NCI does not track how breast cancers are being detected, but certainly the 40,000 women who still die each year were not cured by therapy. The Harvard data suggest that they, likely, were not participating in screening.

\section{Why do women wiht breast cancer do better than men?}

The final piece of evidence that screening and treating breast cancers earlier is the main reason for the decline in breast cancer deaths is seen in the data for men with breast cancer (40). While the death rate for women with breast cancer has fallen dramatically, the same has not been true for men with breast cancer. In 1990, as the death rate for women was beginning to fall, it actually increased for men with breast cancer. Staying elevated for several years it returned to 1990 levels where it has remained, unchanged, while deaths have continued to fall among women. The treatments are the same. The difference is that women are being screened and men are not.

Therapy for breast cancer has improved, but many of the advances are toward delaying death. Cures result from treating breast cancers earlier.

\section{New efforts to limit access to screening}

Many are unaware that there has been an almost continuous effort dating back to the 1970's to limit access to screening (41). More recent efforts to limit access to screening revolve around what have pejoratively been called "The Harms of Screening". We all, periodically, experience some anxiety every day just driving in traffic, but we don't consider this a "harm". It is more accurately described as a "risk" of driving. There are certainly "risks" associated with breast cancer screening.

It is claimed that the "harms" of screening have been weighed against the "benefits" of screening, yet the balance has never been provided. How many fewer "harms" outweigh one avoidable death?

\section{The false claim of "false positives"}

Another pejoratively named "harm" is "false positives". In fact, these are not women who have been falsely told they have breast cancer, but they are simply women who are "recalled" from screening for a few extra pictures or an ultrasound. Approximately $10 \%$ of women will be recalled. This is the same rate as for cervical cancer screening (Pap testing) (42). "Recalls" are inconvenient and may cause anxiety, but most of these women will, ultimately, be reassured that everything is fine. In fact, the ACP admits that "false-positive" results have little effect on psychological health or subsequent mammography adherence" (43). It has been claimed that the anxiety associated with screening "outweighs" the benefit (not dying from breast cancer) among women ages 40-49. Really??!!

It is important to understand that "Recalls" are the only major "harm" that is affected by delaying screening until age 50 and delaying the time between screens. The question remains unanswered: "How many fewer recalls from screening "balance" allowing one woman to die, whose life could be saved by annual screening starting at the age of 40"?

\section{Over diagnosis is over exaggerated}

It is claimed that screening leads to massive "Overdiagnosis" - finding numerous breast cancers that would disappear if left undetected (44). Finding them leads to "overtreatment" for a cancer that would never become clinically evident.

The concept of "overdiagnosis" was initially based on a handful of reports of breast cancers that (miraculously) disappeared without treatment (45) (although at least one woman still died from her metastatic disease). These extremely rare cases have all been clinically evident cancers, yet the (false) claim is that mammographically detected cancers would disappear if left undetected. The "studies" 
making this claim have all be refuted and shown to been scientifically unsupportable (46). One often-cited paper in the New England Journal of Medicine claimed that in 2008 alone there were 70,000 "overdiagnosed" ("fake") cancers" due to screening (47). This was shown by three separate and different analyses to be scientifically unsupportable (48-50), yet it is still quoted as if legitimate. In fact, no one has ever seen a mammographically detected breast cancer disappear on its own. You would think that with 70,000 in one year someone would have seen at least one?! A review of almost 500 cases of breast cancers that were not treated showed that none disappeared or even regressed on follow-up (51).

\section{The age of 50 is a contrived threshold for screening with no scientific support}

Despite the fact that the most lives are saved by annual screening starting at the age of 40 , women are being advised to wait until the age of 50 and then get screened every two years to reduce the "harms". This advice is not only scientifically unsupportable, but it also endangers tens of thousands of women. There are absolutely no data to support using the age of 50 as a threshold for screening. None of the parameters of screening change, abruptly, at the age of 50 or any other age (52). The RCT's proved that screening saves lives for women ages 40-74 PERIOD. It has been clearly shown that women ages 40-49, analyzed separately, have a marked decline in breast cancer deaths (53). The age of 40 is the only science and evidence-based threshold for screening. Since delaying screening will only reduce "recalls", and will have no effect on "overdiagnosis" and "overtreatment", then delaying screening will result in tens of thousands of avoidable deaths just to reduce the anxiety of being recalled!

\section{Despite false claims to the contrary - screening does reduce the rate of advanced cancers}

The claims that screening is ineffective because it does not reduce the rate of advanced cancers is false on several levels. Screening does not have to reduce the rate of advanced cancers to reduce deaths. The probability of successful metastatic spread (the key step in lethality) is directly related to the number of cells in a cancer, and this is directly related to its size $(54,55)$. Lives are saved by reducing the size of cancers within stages (56-60).

The claim is also false because it has been clearly shown that screening does reduce the rate of advanced cancers. This has been shown in the RCT's $(61,62)$, as well as when screening is introduced into the population (63-70).

\section{Shouldn't we only screen high risk women?}

This is another specious recommendation. The Panels that have issued guidelines claim to have only relied on RCT's as proof of benefit. The RCT's have shown a clear benefit for screening women in the general population with a mortality reduction for these women. None of the RCT's stratified by risk so there is no "proof" that screening only high-risk women will save any lives. The highest risk women (BRCA1 and 2 mutation carriers) only account for, at most, $10 \%$ of breast cancers diagnosed each year. If we add women with a family history and other risk factors, these account for another $15 \%$ of breast cancers. In fact, the majority of women diagnosed each year with breast cancer are not at elevated risk. If we were to only screen high risk women, this would mean that $75 \%$ of those who develop breast cancer each year will not have the advantage of early detection.

Can't we can screen every two years and have the same benefit as annual screening?

There has never been an RCT to test the difference between annual and biennial screening, but since cancers do not stop growing, and the risk of metastatic spread increases with increasing tumor size (71), it makes sense that more frequent screening saves more lives (72) and this is supported by the data (73).

The NCI/CISNET models (74) and others (75) all show that the most lives are saved by annual screening starting at the age of 40 . The consequences of the various guidelines have been analyzed (76). They show that annual 
screening starting at the age of 40 reduces deaths by $40 \%$. Waiting until the age of 45 , then screening annually until the age of 55, and then biennially after that (American Cancer Society) reduces deaths by $31 \%$, while biennial after the age of 50 (USPSTF and ACP) only reduces deaths by $23 \%$. In actual numbers, for women who are age 40 today, annual screening starting at the age of 40 saves 29,369 lives while the ACS approach will save 22,829 with the USPSTF and ACP saving only 17,153. Annual screening starting at the age of 40 saves $70 \%$ more lives than waiting until the age of 50 and screening biennially. The ACP and the USPSTF forgot to tell this to women.

\section{Finding ductal carcinoma in situ has likely reduced the rate of invasive cancers}

The more recent efforts to reduce access to breast cancer screening have revolved around concerns that mammography screening leads to massive "overdiagnosis" of breast cancer. In order to arrive at this conclusion, a major publication in the New England Journal of Medicine claimed that in 2008 alone there were more than 70,000 breast cancers that would have disappeared if they had not been discovered by screening (47). Not only has no one ever seen a mammographically detected breast cancer disappear on its own (77), but the authors based their claim on their "best guess" as to what the incidence of breast cancer would have been in 2008 had screening not begun in the mid 1980's in the U.S. They completely ignored the fact that a major U.S. tumor registry in Connecticut clearly showed that the incidence of invasive cancers had been increasing steadily since 1940 (78). This baseline increasing incidence has also been evident in the data from several other countries prior to their institution of screening. Had the authors based the extrapolated incidence of breast cancers using actual data and not their "best guess" which was little increase over time, they would have found that, contrary to their claims, not only was there no excess of invasive breast cancer in the U.S. in 2008, but there were, in fact, fewer invasive cancers than would have been expected. What has thus far been ignored because of all the distractions about screening is the likelihood that removal of DCIS lesions due to mammography screening since the 1980's has reduced the development of subsequent invasive cancers.

There is no question that mammography screening has dramatically increased the detection of Ductal Carcinoma In Situ (DCIS). Because of the major uncertainties as to how best to treat this spectrum of lesions, however, many have argued that this is a "harm" of screening. In fact, it is likely a major benefit from screening.

Prior to the start of mammography screening, DCIS represented only 3-5\% of all breast cancers diagnosed each year. With modern mammography as many as 30\% of breast cancers are now diagnosed as DCIS $(79,80)$. It is thought that all breast cancers begin in the ducts of the breast (although Tabar and colleagues would suggest that there are those that do not) so that DCIS is almost certainly the precursor to most invasive breast cancers. The problem lies in the fact that breast cancers likely take many years, if not decades, to progress from a single cell to an invasive cancer capable of metastatic spread (81). Consequently, the true natural history of breast cancers remains unknown. More recent genetic analyses have even raised questions as to how DCIS progresses to invasive breast cancer. Regardless, it appears that metastatic spread cannot occur until cancer cells gain access to the lymphatics or vascular system outside and surrounding the ducts before metastasis can occur. The amount of time this takes seems to be related to the histologic grade of the in-situ lesion (82). Given sufficient time even low-grade DCIS can become invasive and lethal $(83,84)$.

The unanswered question is whether or not removal of DCIS lesions reduces subsequent invasive cancers. Because national statistics in the U.S. (the SEER - Surveillance Epidemiology and End Results program of the NCI) do not track how cancers are detected, it is difficult to have accurate analyses. 
However, the Connecticut Tumor Registry in the U.S. has collected data back to at least 1940 (85). These data show that the rate of invasive cancers has increased steadily by $1-1.3 \%$ per year for decades. Screening began in the U.S. in the mid 1980's. If the rate of invasive cancers continued to increase at $1-1.3 \%$ per year, and there is no reason to expect that it would not have continued, then by 2008 there were actually fewer invasive cancers than would have been expected (86). There is no way to prove this, but it strongly suggests that the removal of DCIS lesions has prevented the development of invasive breast cancers and is contributing to the major reduction in deaths from breast cancer in the U.S.

\section{The Bottom Line}

Mammography screening is not the ultimate answer to breast cancer, but a universal cure is not even on the horizon. At this time, screening is the best way to save the most lives. Everyone agrees that the most lives are saved by annual screening starting at the age of 40. Ignoring the fact that there is no scientific support for using the age of 50 as a threshold for screening, delaying screening until the age of 50 and then screening every two years will have no effect on "overdiagnosis" and "overtreatment", but it will result in tens of thousands of deaths that could be saved by annual screening starting at the age of 40 .

There are still great uncertainties about the importance of DCIS and certainly about its treatment, but it is likely that the detection of these lesions by mammography screening, and their removal, is the reason that the incidence of invasive breast cancers has declined as part of the overall decline in breast cancer deaths associated with screening.

All women should be provided with accurate information. Women should decide for themselves whether or not to participate in screening. The decision should not be made for them.

\section{Conflict of Interest}

Dr. Kopans is a consultant to DART Imaging which is making mammography devices for China.

\section{References}

1. Kopans DB. Breast cancer screening panels continue to confuse the ANSWER and inject their own biases. Curr Oncol. 2015;22(5):e376-9.

2. Kopans DB. Bias in the medical journals: a commentary. AJR Am J Roentgenol. 2005;185(1):176-7.

3. Kopans DB. More misinformation on breast cancer screening. Gland Surg. 2017;6(1):125-129.

4. Kopans DB. Informed decision-making: age of 50 is arbitrary and has no demonstrated influence on breast cancer screening in women. AJR Am J Roentgenol. 2005;185(1):177-82.

5. Press release from the National Medical Roundtable on Mammography Screening Guidelines. June 27, 1989.

6. Kopans DB, Halpern E, Hulka CA. Statistical Power in Breast Cancer Screening Trials and Mortality Reduction Among Women 40-49 with Particular Emphasis on The National Breast Screening Study of Canada. Cancer. 1994;74(4):1196-203.

7. House Committee on Government Operations. Misused Science: The National Cancer Institutes Elimination of Mammography Guidelines for Women in Their Forties. Union Calendar No. 480. House Report 103-863. October 20, 1994.

8. Hendrick RE, Smith RA, Rutledge JH, Smart CR. Benefit of screening mammography in women ages 40-49: a new meta- analysis of randomized controlled trials. J Natl Cancer Inst Monogr. 1997;(22):87-92.

9. https://academic.oup.com/jnci/article-lookup/doi/10.1093/jnci/89.8.538 LAST ACCESSED 4/23/2019.

10. Armstrong K, Moye E, Williams S, Berlin JA, Reynolds EE. Screening mammography in women 40 to 49 years of age: a systematic review for the American College of Physicians. Ann Intern Med. 2007:146(7):516-26.

11. US Preventive Services Task Force. Screening for breast cancer: U.S. Preventive Services Task Force recommendation statement. Ann Intern Med. 2009;151(10):716-26.

12. Siu AL; U.S. Preventive Services Task Force. Screening for Breast Cancer: U.S. Preventive Services Task Force Recommendation Statement. Ann Intern Med. 2016;164(4):279-96.

13. Qaseem A, Lin JS, Mustafa RA, Horwitch CA, Wilt TJ; Clinical Guidelines Committee of the American College of Physicians, et al. Screening for Breast Cancer in Average-Risk Women: A Guidance Statement From the American College of Physicians. Ann Intern Med. 2019;170(8):547-560.

14. Hendrick RE, Helvie MA. USPSTF Guidelines on Screening Mammography Recommendations: Science Ignored. AJR Am J Roentgenol. 2011; 196(2):W112-6.

15. Smith RA, Duffy SW, Gabe R, Tabár L, Yen AM, Chen TH. The randomized trials of breast cancer screening: what have we learned? Radiol Clin North Am 2004:42(5):793-806.

16. Tabár L, Yen AM, Wu WY, Chen SL, Chiu SY, Fann JC, et al. Insights from the breast cancer screening trials: how screening affects the natural history of breast cancer and implications for evaluating service screening programs. Breast J. 2015;21(1):13-20.

17. Hendrick RE, Smith RA, Rutledge JH, Smart CR. Benefit of screening mammography in women ages 40-49: a new meta- analysis of randomized controlled trials. J Natl Cancer Inst Monogr. 1997;(22):87-92.

18. Tabar L, Vitak B, Tony HH, Yen MF, Duffy SW, Smith RA. Beyond randomized controlled trials: organized mammographic screening substantially reduces breast carcinoma mortality. Cancer. 2001;91(9):1724-31.

19. Kopans DB. Beyond randomized controlled trials: organized mammographic screening substantially reduces breast carcinoma mortality. Cancer. 2002;94(2):580-1; author reply 581-3.

20. Duffy SW, Tabar L, Chen H, Holmqvist M, Yen M, Abdsalah S, et al. The Impact of Organized Mammography Service Screening on Breast Carcinoma Mortality in Seven Swedish Counties. Cancer. 2002;95(3):458-69.

21. Otto SJ, Fracheboud J, Looman CWN, Broeders MJM, Boer R, Hendriks 
JNHCL, et al. Initiation of population-based mammography screening in Dutch municipalities and effect on breast-cancer mortality: a systematic review. Lancet. 2003;361(9367):1411-7.

22. Swedish Organised Service Screening Evaluation Group. Reduction in breast cancer mortality from organized service screening with mammography: 1. Further confirmation with extended data. Cancer Epidemiol Biomarkers Prev. 2006;15(1):45-51.

23. Coldman A, Phillips N, Warren L, Kan L. Breast cancer mortality after screening mammography in British Columbia women. Int J Cancer. 2007; 120(5):1076-80.

24. Jonsson $H$, Bordás P, Wallin H, Nyström L, Lenner P. Service screening with mammography in Northern Sweden: effects on breast cancer mortality - an update. J Med Screen. 2007;14(2):87-93.

25. Paap E, Holland R, den Heeten GJ, van Schoor G, Botterweck AAM, Verbeek ALM, et al. A remarkable reduction of breast cancer deaths in screened versus unscreened women: a case-referent study. Cancer Causes Control. 2010;21(10):1569-73

26. Otto SJ, Fracheboud J, Verbeek ALM, Boer R, Reijerink-Verheij JCIY, Otten JDM, et al. Mammography screening and risk of breast cancer death: a population-based case-control study. Cancer Epidemiol Biomarkers Prev. 2012:21(1):66-73. Epub 2011 Dec 6.

27. van Schoor G, Moss SM, Otten JD, Donders R, Paap E, den Heeten GJ, et al. Increasingly strong reduction in breast cancer mortality due to screening. Br J Cancer. 2011;104(6):910-4

28. Mandelblatt JS, Cronin KA, Bailey S, Donald A Berry, Harry J de Koning, Gerrit Draisma, et.al. Effects of mammography screening under different screening schedules: model estimates of potential benefits and harms. Ann Intern Med. 2009:151(10):738-47.

29. Hellquist BN, Duffy SW, Abdsaleh S, Björneld L, Bordás P, Tabár L, Viták B Zackrisson S, Nyström L, Jonsson $H$. Effectiveness of population-based service screening with mammography for women ages 40 to 49 years: evaluation of the Swedish Mammography Screening in Young Women (SCRY) cohort. Cancer. 2011;117(4):714-22.

30. Broeders M, Moss S, Nyström L, Njor S, Jonsson H, Paap E, Massat N Duffy S, Lynge E, Paci E; EUROSCREEN Working Group. The impact of mammographic screening on breast cancer mortality in Europe: a review of observational studies. J MedScreen. 2012:19 Suppl 1:14-25

31. Hofvind S, Ursin G, Tretli S, Sebuødegtrd S, Møller B. Breast cancer mortality in participants of the Norwegian Breast Cancer Screening Program. Cancer. 2013;119(17):3106-12

32. Sigurdsson K, Olafsdóttir EJ. Population-based service mammography screening: the Icelandic experience. Breast Cancer (Dove Med Press). 2013; 5:17-25

33. Coldman A, Phillips N, Wilson C, Decker K, Chiarelli AM, Brisson J, et al Pan-canadian study of mammography screening and mortality from breast cancer. J Natl Cancer Inst. 2014; 106(11):dju261.

34. Puliti D, Bucchi L, Mancini S, Paci E, Baracco S, Campari C, et al. Advanced breast cancer rates in the epoch of service screening: The 400,000 women cohort study from Italy. Eur J Cancer. 2017;75:109-116.

35. Webb ML, Cady B, Michaelson JS, Bush DM, Calvillo KZ, Kopans DB, et al. A failure analysis of invasive breast cancer: most deaths from disease occur in women not regularly screened. Cancer. 2014:120(18):2839-46.

36. Spencer DB, Potter JE, Chung MA, Fulton J, Hebert W, Cady B. Mammographic screening and disease presentation of breast cance patients who die of disease. Breast J. 2004;10(4):298-303

37. Duffy SW, Tabár L, Yen AM, Dean PB, Smith RA, Jonsson H, et al. Mammography screening reduces rates of advanced and fatal breast cancers: Results in 549,091 women. Cancer. 2020:126(13):2971-2979.

38. Kopans DB. Beyond randomized controlled trials: organized mammographic screening substantially reduces breast carcinoma mortality. Cancer. 2002;94(2):580-1; author reply 581-3.

39. Hendrick RE, Baker JA, Helvie MA. Breast cancer deaths averted over 3 decades. Cancer. 2019;125(9):1482-1488.

40. http://seer.cancer.gov/csr/1975_2010/results_merged/sect_04_breast.pdf --- Table 4.6 Last accessed 5/13/2021.

41. Kopans DB. The Breast Cancer Screening "Arcade" and the "Whack-A-Mole" Effortsto Reduce Access to Screening. Semin Ultrasound CT MR. 2018;
39(1):2-15.

42. Saraiya M, Irwin KL, Carlin L, Chen X, Jain N, Benard V, Montano DE. Cervical cancer screening and management practices among providers in the National Breast and Cervical Cancer Early Detection Program (NBCCEDP). Cancer. 2007;110(5):1024-32.

43. Armstrong K, Moye E, Williams S, Berlin JA, Reynolds EE. Screening mammography in women 40 to 49 years of age: a systematic review for the American College of Physicians. Ann Intern Med. 2007;146(7):516-26.

44. Zahl PH, Mșhlen J, Welch HG. The Natural History of Invasive Breast Cancers Detected by Screening Mammography. ArchlnternMed. 2008; 168(21):2311-2316

45. Larsen SU, Rose C. [Spontaneous remission of breast cancer. A literature review]. Ugeskr Laeger. 1999;161(26):4001-4. Danish.

46. Puliti D, Duffy SW, Miccinesi G, de Koning H, Lynge E, Zappa M, et al. Overdiagnosis in mammographic screening for breast cancer in Europe: a literature review. J Med Screen. 2012;19 Suppl 1:42-56.

47. Bleyer $\mathrm{A}$, Welch $\mathrm{HG}$. Effect of three decades of screening mammography on breast-cancer incidence. N Engl J Med. 2012;367(21):1998-2005.

48. Kopans DB. Arguments against mammography screening continue to be based on faulty science. Oncologist. 2014;19(2):107-12.

49. Helvie MA, Chang JT, Hendrick RE, Banerjee M. Reduction in late-stage breast cancer incidence in the mammography era: Implications for overdiagnosis of invasive cancer. Cancer. 2014:120(17):2649-56.

50. Etzioni R, Xia J, Hubbard R, Weiss NS, Gulati R. A reality check for overdiagnosis estimates associated with breast cancer screening. J Natl Cancer Inst. 2014;106(12):dju315.

51. Arleo EK, Monticciolo DL, Monsees B, McGinty G, Sickles EA. Persistent untreated screening-detected breast cancer: an argument against delaying screening or increasing the interval between screenings. J Am Coll Radiol 2017:14:863-867.

52. Kopans DB, Moore RH, McCarthy KA, Hall DA, Hulka C, Whitman GJ, et al. Biasing the Interpretation of Mammography Screening Data By Age Grouping: Nothing Changes Abruptly at Age 50. Br J Cancer. 2004; 90(1): 139-45.

53. Hendrick RE, Smith RA, Rutledge JH, Smart CR. Benefit of screening mammography in women ages 40-49: a new meta- analysis of randomized controlled trials. J Natl Cancer Inst Monogr. 1997;(22):87-92.

54. Michaelson JS, Halpern E, Kopans DB. Breast cancer: computer simulation method for estimating optimal intervals for screening. Radiology. 1999:212(2):551-60.

55. Michaelson JS, Silverstein M, Wyatt J, Weber G, Moore R, Halpern E, et al. Predicting the survival of patients with breast carcinoma using tumor size. Cancer. 2002;95(4):713-23.

56. Quiet CA, Ferguson DJ, Weichselbaum RR, Hellman S. Natural history of node-negative breast cancer: a study of 826 patients with long-term follow-up. J Clin Oncol. 1995;13(5):1144-51.

57. Saadatmand S, Bretveld R, Siesling S, Tilanus-Linthorst MM. Influence of tumour stage at breast cancer detection on survival in modern times: population-based study in 173,797 patients. BMJ. 2015;351:h4901.

58. Elkin EB, Hudis C, Begg CB, Schrag D. The effect of changes in tumor size on breast carcinoma survival in the U.S.: 1975-1999. Cancer. 2005; 104(6):1149-57.

59. Rosen PP, Groshen S, Saigo PE, Kinne DW, Hellman S. A long-term follow-up study of survival in stage I (T1 NO M0) and stage II (T1 N1M0) breast carcinoma. J Clin Oncol. 1989;7(3):355-66.

60. Chu KC, Smart CR, Tarone RE. Analysis of breast cancer mortality and stage distribution by age for the Health Insurance Plan clinical trial. J Natl Cancer Inst. 1988;80(14):1125-32

61. Tabár L, Yen AM, Wu WY, Chen SL, Chiu SY, Fann JC, et al. Insights from the breast cancer screening trials: how screening affects the natural history of breast cancer and implications for evaluating service screening programs. Breast J. 2015;21(1):13-20.

62. Smith RA, Duffy SW, Gabe R, Tabár L, Yen AM, Chen TH. The randomized trials of breast cancer screening: what have we learned? Radiol Clin North Am 2004;42(5):793-806.

63. Anderson WF, Jatoi I, Devesa SS. Assessing the impact of screening mammography: Breast cancer incidence and mortality rates in Connecticut (1943-2002). Breast Cancer Res Treat. 2006;99(3):333-40. 
64. Helvie MA, Chang JT, Hendrick RE, Banerjee M. Reduction in late-stage breast cancer incidence in the mammography era: Implications for overdiagnosis of invasive cancer. Cancer. 2014;120(17):2649-56.

65. Puliti D, Bucchi L, Mancini S, Paci E, Baracco S, Campari C, et al. Advanced breast cancer rates in the epoch of service screening: The 400,000 women cohort study from Italy. Eur J Cancer. 2017;75:109-116.

66. Tabár L, Yen AM, Wu WY, Chen SL, Chiu SY, Fann JC, et al. Insights from the breast cancer screening trials: how screening affects the natural history of breast cancer and implications for evaluating service screening programs. Breast J. 2015;21(1):13-20.

67. Foca F, Mancini S, Bucchi L, Puliti D, Zappa M, Naldoni C, et al. Decreasing incidence of late-stage breast cancer after the introduction of organized mammography screening in Italy. Cancer. 2013;119(11):2022-8.

68. Swedish Organised Service Screening Evaluation Group. Effect of mammographic service screening on stage at presentation of breast cancers in Sweden. Cancer. 2007;109(11):2205-12.

69. Oberaigner W, Geiger-Gritsch S, Edlinger M, Daniaux M, Knapp R, Hubalek $M$, et al. Reduction in advanced breast cancer after introduction of a mammography screening program in Tyrol/Austria. Breast. 2017;33:178-182.

70. Malmgren JA, Parikh J, Atwood MK, Kaplan HG. Impact of mammography detection on the course of breast cancer in women aged 40-49 years. Radiology. 2012;262(3):797-806.

71. Michaelson J, Satija S, Kopans D, Moore R, Sliverstein M, Comegno A, et al. Gauging the impact of breast carcinoma screening in terms of tumor size and death rate. Cancer. 2003:98(10):2114-24.

72. Michaelson JS, Halpern E, Kopans DB. Breast cancer: computer simulation method for estimating optimal intervals for screening. Radiology. 1999; 212(2):551-60

73. Price ER, Keedy AW, Gidwaney R, Sickles EA, Joe BN. The Potential Impact of Risk-Based Screening Mammography in Women 40-49 Years Old. AJR Am J Roentgenol. 2015;205(6):1360-4.

74. Siu AL; U.S. Preventive Services Task Force. Screening for Breast Cancer: U.S. Preventive Services Task Force Recommendation Statement. Ann Intern Med. 2016;164(4):279-96.

75. Michaelson JS, Halpern E, Kopans DB. Breast cancer: computer simulation method for estimating optimal intervals for screening. Radiology. 1999; 212(2):551-60.
76. Arleo EK, Hendrick RE, Helvie MA, Sickles EA. Comparison of recommendations for screening mammography using CISNET models. Cancer. 2017; 123(19):3673-3680.

77. Arleo EK, Monticciolo DL, Monsees B, McGinty G, Sickles EA. Persistent untreated screening-detected breast cancer: an argument against delaying screening or increasing the interval between screenings. J Am Coll Radiol. 2017;14(7):863-867.

78. Anderson WF, Jatoi I, Devesa SS. Assessing the impact of screening mammography: Breast cancer incidence and mortality rates in Connecticut (1943-2002). Breast Cancer Res Treat. 2006;99(3):333-40.

79. Ernster VL, Barclay J, Kerlikowske K, Grady D, Henderson IC. Incidence of and Treatment for Ductal Carcinoma In Situ of the Breast. JAMA. 1996; 275(12):913-918.

80. Ernster VL, Ballard-Barbash R, Barlow WE, Zheng Y, Weaver DL, Cutter G, et al. Detection of ductal carcinoma in situ in women undergoing screening mammography. J Natl Cancer Inst. 2002;94(20):1546-54.

81. Kopans DB, Rafferty E, Georgian-Smith D, Yeh E, D'Alessandro H, Moore R, et al. A simple model of breast carcinoma growth may provide explanations for observations of apparently complex phenomena. Cancer. 2003:97(12): 2951-9.

82. Duffy SW, Dibden A, Michalopoulos D, Offman J, Parmar D, Jenkins J, et al. Screen detection of ductal carcinoma in situ and subsequent incidence of invasive interval breast cancers: a retrospective population-based study. Lancet Oncol. 2016;17(1):109-14. Epub 2015 Dec 5.

83. Page DL, Dupont WD, Rogers LW, Jenson RA, Schuyler PA. Continued local recurrence of carcinoma 15-25 years after a diagnosis of low grade ductal carcinoma in situ of the breast treated only by biopsy. Cancer. 1995; 76(7):1197-200.

84. Sanders ME, Schuyler PA, Simpson JF, Page DL, Dupont WD. Continued observation of the natural history of low-grade ductal carcinoma in situ reaffirms proclivity for local recurrence even after more than 30 years of follow-up. Mod Pathol. 2015;28(5):662-9.

85. Anderson WF, Jatoi I, Devesa SS. Assessing the impact of screening mammography: Breast cancer incidence and mortality rates in Connecticut (1943-2002). Breast Cancer Res Treat. 2006;99(3):333-40.

86. Kopans DB. Arguments against mammography screening continue to be based on faulty science. Oncologist. 2014;19(2):107-12. 